\title{
A Model of the Daily Energy Budget and Energy Flow Through a Population of the White-footed Mouse
}

\author{
Stephen L. BAAR \& Eugene D. FLEHARTY
}

\begin{abstract}
Baar S. L. \& Fleharty E. D., 1976: A model of the daily energy budget and energy flow through a population of the white-footed mouse. Acta theriol., 21, 12: 179-193 [With 2 Tables \& 3 Figs.]

Daily energy budgets (DEBs), activity patterns and the energy flow through a population of Peromyscus leucopus ( $\mathrm{R}$ a fin es que, 1818) were studied for one year. The $D E B$ for the nonlactating portion of the population was the highest in winter $(0.602 \mathrm{kcal} / \mathrm{gm}$ day $)$ and lowest in summer $(0.307 \mathrm{kcal} / \mathrm{gm}$ day). The $D E B$ of lactating females in summer was 24.8 per cent greater than that of males and nonlactating females from the same season. During winter the animals spent 72 per cent of the day in the nest, whereas in summer males and nonlactating females spent only 28 per cent of the day in the nest. Energy flow through the population was maximal in autumn (396.3 kcal/ha day) when the biomass $(715.86 \mathrm{gm} / \mathrm{ha}$ day) was greatest and minimal in spring (170.4 $\mathrm{kcal} / \mathrm{h}$ a day) when the biomass $(327.54 \mathrm{gm} / \mathrm{ha}$ day) was least. Different intensities of simulated moonlight were found to have no significant effect upon the activity of the white-footed mouse in any season.

[Fort Hays Kansas State Coll., Hays, Kansas 67601, USA]
\end{abstract}

\section{INTRODUCTION}

The purpose of this study was to determine the DEB of Peromyscus leucopus throughout the year by use of a respirometer that incorporated both daily and seasonal variation in temperature and light (photoperiod and intensity) in the activity chamber, and seasonal changes in the temperature of an adjoining nest chamber. These $D E B$ s include the time and energy expended in the nest, out of the nest, and exercising. The bioenergetic values obtained from this laboratory study then were applied to data on population structure and secondary production of $P$. leucopus to construct a model for energy flow in the species on the central Great Plains.

The white-footed mouse is a Cricetine rodent whose range includes most of North America east of the Rocky Mountains from Canada to southern Mexico ( $\mathrm{Hall}$ \& Kelson, 1959). The habitat of P. leucopus is chiefly woodland communities and on the Great Plains is often restricted to wooded areas along watercourses where they feed almost entirely upon seeds and insects ( $\mathrm{Ch}$ oate \& Fleh a r ty, 1975). 
Energy flow $\left(E_{f}\right)$ through a population is the sum of the energy used for maintenance $\left(E_{m}\right)$ plus the energy used for growth $\left(E_{g}-\mathrm{C}\right.$ olley, 1960; Ryszkowski \& Petrusewicz, 1967; Chew \& Chew, 1970; O d u m, 1971). Of the two components of energy flow the energy for maintenance is by far the most significant, comprising approximately 98 per cent of the annual energy flow (F leharty \& Choate, 1973). Therefore, although the amount of energy channeled into secondary production is important in maintaining the population, a precise measurement of the energy of maintenance is crucial if accurate determinations of energy flow through a population are to be made.

Currently few methods for measuring the energy expenditure of freeliving animals are both reliable and economically feasible (G e s s a m a n, 1973). Because most measurements of metabolism involve captive animals the estimates may fail to accurately predict energy flow in a free-living population. In previous studies the energy expended at different regimes of temperature, light, and other environmental factors found in a natural system usually have not been measured separately, and often times are not considered. By neglecting the effect of these natural parameters the extent to which they influence the animal is disregarded and the estimated amount of energy expended by a free-living animal is almost certainly not correct.

The design of the respirometer (B a r \& Fleharty, 1973) used in this study facilitated direct measurements of the time spent in the three states of behavior experienced by an animal (i.e. at rest in the nest, at rest outside the nest, and active outside the nest) and the energy expended in these areas, the sum of which gives the daily energy budget $(D E B)$ of the animal. A model of the $D E B$ can then be constructed as follows:

where $G=$ biomass

$$
D E B=G\left[\left(H_{r n} \times E_{r n}\right)+\left(H_{r o} \times E_{r o}\right)+\left(H_{a} \times E_{a}\right)\right]
$$

$H_{r n}=$ hours per day resting in nest

$E_{r n}=$ metabolic rate while resting in nest

$H_{r .}^{r n}=$ hours per day resting outside nest

$E_{r o}=$ metabolic rate while resting outside nest

$H_{a}=$ total hours per day active outside nest

and $E_{a}=$ metabolic rate while active outside nest.

\section{MATERIALS AND METHODS}

\section{Laboratory studies}

Specimens of Peromyscus leucopus were trapped periodically from September of 1972 through August of 1973 in $7.6 \times 7.6 \times 22.9 \mathrm{~cm}$ Sherman live traps baited with rolled oats and corn. Specimens were taken from various wooded riparian habitats within an $11.3 \mathrm{~km}$ radius of Hays, Kansas $\left(38^{\circ} 50^{\prime} \mathrm{N}, 99^{\circ} 22^{\prime} \mathrm{W}\right)$. Data 
were treated on a seasonal basis (Autumn=September, October, November; Winter= December, January, February; Spring=March, April, May; Summer=June, July, August).

Within 12 hours after they were trapped, animals were brought into the laboratory where their weight, age, sex, and reproductive condition was determined and recorded. Animals which appeared unhealthy were not used; results obtained from animals which died or exhibited abnormal behavior during experimentation were excluded from further analysis. Because few juveniles were obtained for metabolic studies, the metabolic rate (on a per gram basis) of nonlactating adults was used to calculate $D E B$ s for juveniles. Although admittedly an error, this simplification will result in a conservative estimate of energy flow in the field as metabolic rate per unit of weight is inversely related to body weight.

$D E B S$ were determined by measuring oxygen consumption in an open system in which the nest and activity chamber, connected by a runway, could be kept at ambient temperatures experienced by mice under natural conditions in their nests and above ground at both different times during the day and at various times during the year. This respirometer and associated recording equipment has been described in detail previously (B a a \& \& F leh a r ty, 1973) with the two following changes made for this study: (1) the photoelectric devices in the runway were replaced with a treadle and mercury switch; and (2) the compressed gas supply was replaced with a small pump (vibrator type) which forced external air through the system.

Temperature of the soil at a depth similar to that of a subterranean nest of P. leucopus at Hays, Kansas (E. D. Fleharty, pers. comm.), was taken from U. S. Weather Bureau data (unpublished) for the date of each run. The temperature of the nest chamber was set at this value 4 to 8 hours before placing an animal in the respirometer for acclimation, and was maintained at this temperature $\left( \pm 0.5^{\circ} \mathrm{C}\right)$ throughout the run. Data from the U. S. Dept. of Commerce weather station at Hays (located within $11.2 \mathrm{~km}$ of the study area) provided the daily maximum and minimum surface air temperatures based on a ten year average. It was assumed that in the field the maximum temperature occurred in mid-afternoon and the minimum just prior to sunrise. The diel temperature of the activity chamber curresponded to this pattern.

The time of moonrise or moonset, if they occurred, and sunrise and sunset for the date of each run was determined and the artificial lighting system in the activity chamber was set to simulate these regimes of natural light. Food and water ad libitum and cotton for nesting material also were placed in the activity chamber prior to each run.

After connecting the recording equipment, the animal was placed in the respirometer (Baar \& Fleharty, 1973) and the system was closed and checked for leaks. A period of 18-24 hours was allowed for acclimation of the animal during which time he usually constructed a nest in the nest chamber and in general appeared to adjust to the respirometer. After acclimation, oxygen consumption, temperatures of the nest and activity chamber, and the animal's state of activity (i.e. in the nest, in the activity chamber not running, or running in an activity wheel in the activity chamber) was recorded continuously for 24 hours. At the end of the run the animal was removed and weighed; the average of the initial and final weights was used in all calculations. $D E B$ s for lactating females with their young were determined by weighing the mother and young together and then placing them in the respirometer as described above. 
Data from oxygen consumption studies were analyzed by computer programs developed by J. R. Brethour (Fort Hays branch of the Kansas State Experimental Station, Hays, Kansas). The phase I program computed oxygen consumption in cubic centimeters per gram per hour at ten minute intervals for the 24-hour period, and also the average daily metabolic rate (cc/gm $\mathrm{hr}$ ) based on the readings for each ten minute interval. The amount of oxygen consumed was converted to caloric values to give $D E B$ s assuming a respiratory quotient of 0.8 at which 1 liter of oxygen is equivalent to $4.8 \mathrm{kcal}$. The phase II program computed correlation coefficients between oxygen consumption and sixteen variables: eight of these dealt with light regimes, six with activity, and two with temperature. Statistical significance was tested at the 95 per cent and 99 per cent confidence levels.

\section{Field studies}

Population studies were carried out on a 0.57 hectare plot along Big Creek on the Fort Hays Kansas State College campus (SE 1/4 sec. 5, T. 14S, R. 18W, Ellis Co., KS) from October of 1972 through September of 1973 (S m r ck a, 1974). Animals were live-trapped during the first two weeks of each month in Sherman live traps $(7.6 \times 7.6 \times 22.9 \mathrm{~cm})$ set throughout the study area at sites thought likely to be visited by Peromyscus leucopus (L a y e, 1954). Methods described by Fle ha r ty \& $\mathrm{M}$ ares (1973) and $\mathrm{Hansen} \& \mathrm{Fleh}$ art y (1974) were used in marking animals and recording data. Crude densities were estimated from the actual number of mice captured by means of the »capture calendar method" (A ndrzejews ki, 1963, 1967).

Biomass present during each season was determined by multiplying the average weight of each animal by the estimated number of days he was on the study area during the season and summing these values for all animals found on the study area. This biomass figure was subdivided into two categories: (1) juveniles and adult males and nonlactating females, and (2) lactating females.

Secondary production for each season was calculated as the sum of the increase in biomass (i.e. growth) of each individual known to be present during the season plus the estimated biomass contributed by reproduction during the season.

\section{RESULTS}

A total of thirty-nine animals was studied in the laboratory during a one year period. All individuals obtained during the same season were treated as a single group (for purposes of comparison and statistical analysis) with the exception of the sample from summer, wherein lactating and nonlactating (male and female) animals were treated as two separate groups; thus, a total of five groups was studied. For each of these five groups a model of the $D E B$ was determined.

$D E B$ of males and females did not differ significantly within any season or throughout the year; therefore, with the exception of lactating females, the sexes were pooled for subsequent analyses. Also, there was no significant difference in the average weights of specimens examined among seasons, although the population during summer when a large number $(32 \%)$ of the mice were pregnant had the greatest mean weight (Table 1). 
The average $D E B$ of nonlactating (male and female) $P$. leucopus was greatest in winter, lower in spring and autumn and least in summer (Table 1). Summer values for nonlactating mice differed significantly $(P=.05)$ from values for winter and spring, but not from autumn values. No significant differences were found among $D E B$ s for nonlactating (male and female) mice in autumn, winter, or spring or for lactating mice in summer.

Data obtained in the field showed the crude density of adult and juvenile mice during winter to be 28.1 per hectare (Fig. 1) and total biomass-days for the season to be $48,990.5$ gram-days per hectare (Table 1). No pregnant or lactating mice were present during this season.

Table 1

A model of the daily energy budget ( $D E B-\mathrm{kcal} / \mathrm{g}$ day) of nonlactating animals in each season and lactating animals with their young $(L+Y)$ in summer as determined in the laboratory. $H_{r n}, H_{r o}, H_{a}=$ time (hrs/day) resting in the nest, resting outside the nest and active, respectively. $E_{r n}, E_{r o}, E_{a}=$ metabolic rate (kcal/ /gm hr) while resting in the nest, resting outside the nest and active, respectively. Per cent values in parenthesis indicate amount of the day in each activity.

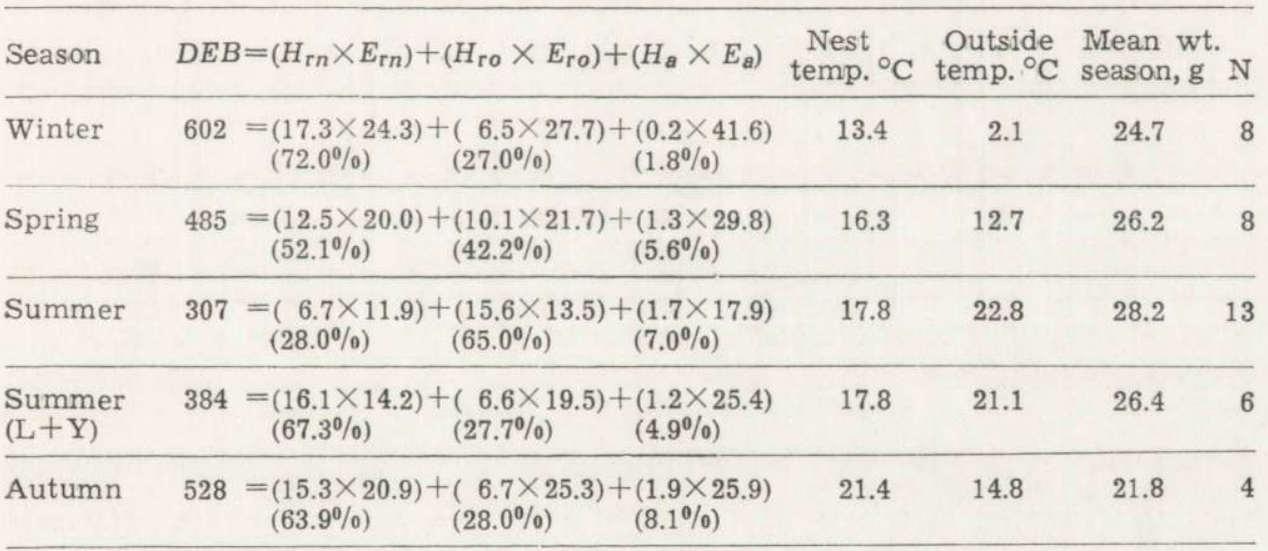

The average $D E B$ of individual mice during winter (as determined in the laboratory) was the greatest $\left(0.602 \mathrm{kcal} / \mathrm{gm}\right.$ day $\left.=5.24 \mathrm{cc} \mathrm{O}_{2} / \mathrm{gm} \mathrm{hr}\right)$ of all seasons. This was expected, as the mean temperatures of both the nest and activity chamber were least in winter (Table 2). In winter the animals spent nearly all $(72.0 \%)$ of their time in the nest and were outside the nest running on the activity wheel only 1.8 per cent of the time (Table 2). The daily pattern of activity for nonlactating animals in all seasons was, for the most part, the same as that in winter (Fig. 2). This was characterized by a nocturnal period of activity (increasing at sunset and decreasing at sunrise) with another period of activity at approximately midday. The activity during daylight hours was found in all seasons 
(e.g. compare Fig. 2 and Fig. 3) although these animals are generally considered to be nocturnal. Oxygen consumption curves for an average 24-hour day during winter (Fig. 2) generally follow the pattern of activity, with the greatest rate of consumption being at night and a small increase at midday. Combining rates of metabolism determined in the laboratory and data on biomass from the field yields an energy flow value for the winter population (Table 1) which is second only to that of autumn. Energy of maintenance during winter is also nearly as great as in autumn. Energy devoted to secondary production during winter was only 0.24 per cent of the total energy flow and was the lowest of any season, all of this energy being channeled into growth (Table 1). No reproduction (Table 1) occurred in winter and little growth as most of the population entering this season were adults.

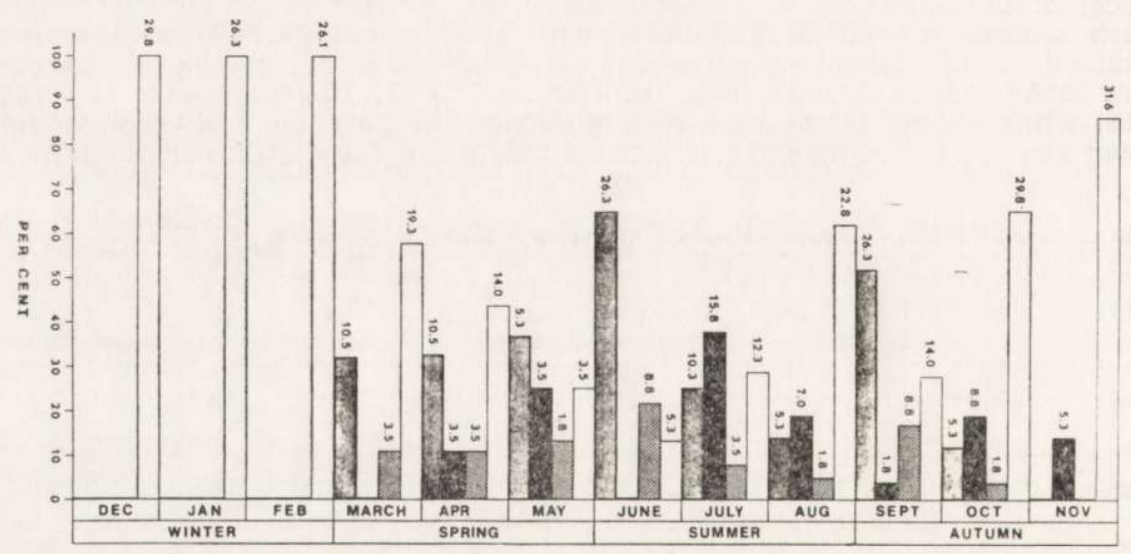

Fig. 1. Density of Peromyscus leucopus.

Bars represent the per cent of the total population made up by the different segments of the population: gray $=$ neonates, black $=$ juveniles, stippled $=$ lactating females, white $=$ nonlactating (male and female) adults. Numbers adjacent to the bars indicate the actual density of animals per hectare.

Crude density during spring (26.3 animals/ha; Fig. 1) was the least observed during any season as was the total biomass-days $(30,133.6$ gramdays/ha; Table 2). The average $D E B$ for a nonclactating white-footed mouse in spring $\left(0.485 \mathrm{kcal} / \mathrm{gm}\right.$ day $\left.=4.20 \mathrm{cc} \mathrm{O}_{2} / \mathrm{gm} \mathrm{hr}\right)$ was lower than that of winter; however, the temperatures of the nest and activity chamber were warmer than in winter. Mice spent much less time $(52.0 \%$ of the day) in the nest and more time ( $7.0 \%$ of the day) running on the activity wheel in spring than in winter (Table 1). This also may have been due to warmer temperatures in the activity chamber during spring. The average activity pattern for a 24-hour period during spring exhibit- 
ed the same general features as during winter, but more time was spent out of the nest during the daylight hours in spring (see Fig. 2). Nearly all of the time that was spent running occurred at night, with the greatest amount just after sunset, and (as in winter) there was an increase in both activity and oxygen consumption at about midday. The 24-hour oxygen consumption curve (Fig. 2) is generally the same shape as that of winter and is also a reflection of activity.
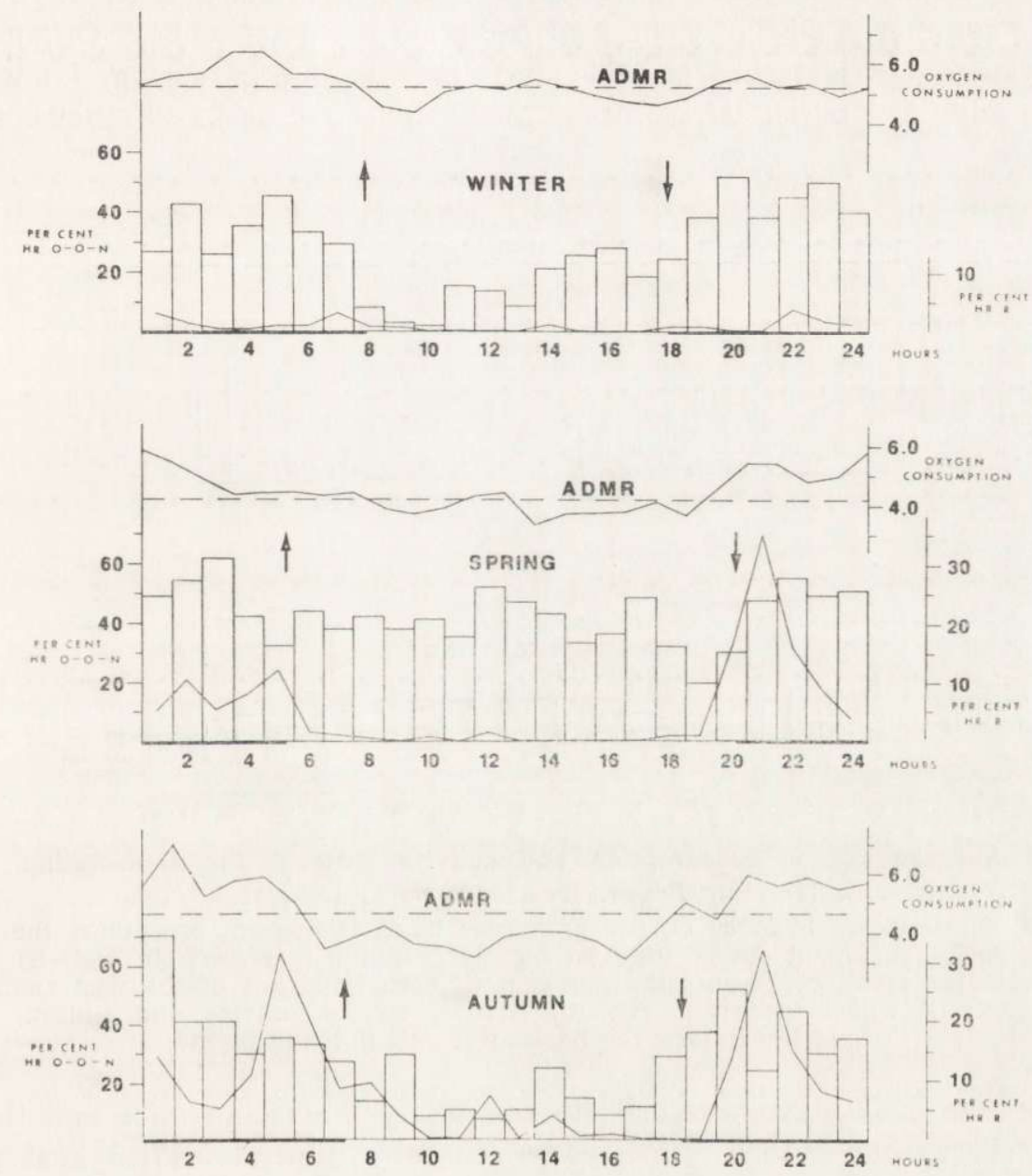

Fig. 2. Average oxygen consumption and activity patterns for nonlactating Peromyscus leucopus in three seasons.

Oxygen consumption is in $\mathrm{cc}_{2}$ per gram per hour. Histogram represents the per cent of each hour spent out of the nest but not running on the activity wheel (per cent $\mathrm{Hr}$. O-O-N) and the associated curve represents the per cent of each hour out of the nest running in an activity wheel (per cent Hr. R). Arrows denote sunrise and sunset. The bold lines along the horizontal axis indicate night. 
Total energy flow (Table 2) for the population of white-footed mice in spring was the least for the year $(16,120.3 \mathrm{kcal} / \mathrm{ha})$. More $(2.73 \%)$ of the total energy flow through the population was being channeled into secondary production during this season than in winter as reproduction and consequently growth of new-born individuals was beginning (Table 2). During spring the density of lactating females was estimated to be 2.9 per hectare, or 11 per cent of the population. Using the same $(24.8 \%)$ increase in metabolism as found for lactating animals and their young during summer, a $D E B$ of $0.602 \mathrm{kcal}$ per gram per day ( $=5.24 \mathrm{cc} \mathrm{O}_{2} / \mathrm{gm} \mathrm{hr}$ ) is obtained for lactating animals and their young in spring. Lay $\mathrm{n}$ (1968) gave the period of lactation for P. leucopus as 22-37 days, and
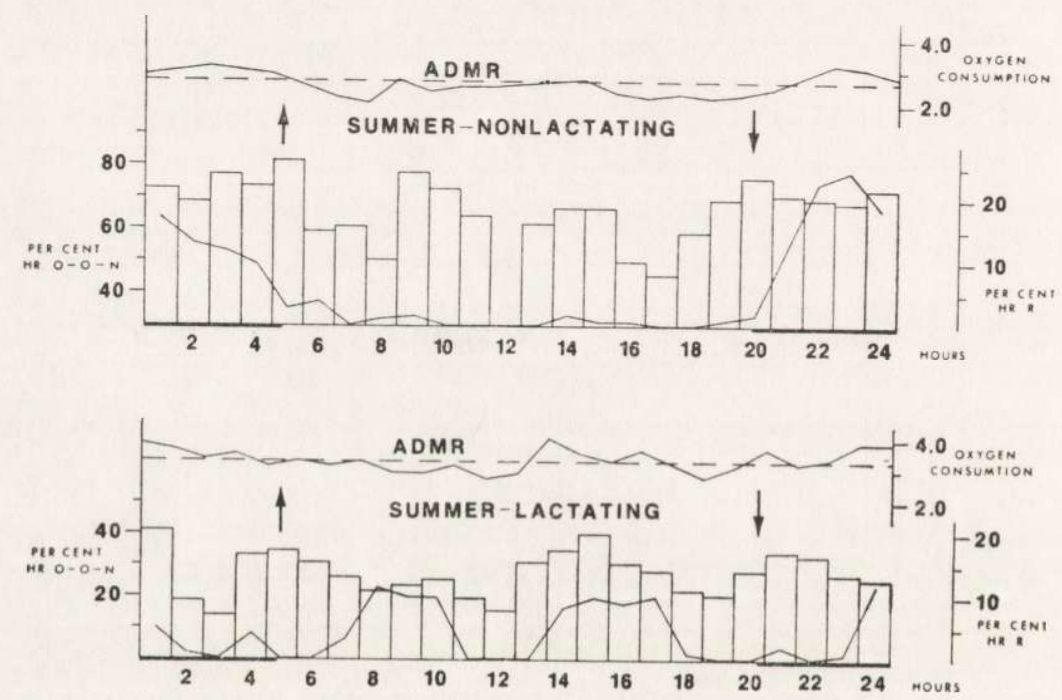

Fig. 3. Average oxygen consumption and activity patterns for nonlactating and lactating Peromyscus leucopus in summer.

Oxygen consumption is in cc $\mathrm{O}_{2}$ per gram per hour. Histogram represents the per cent of each hour spent out of the nest but not running (per cent $\mathrm{Hr}$. O-O-N) and the associated curve represents the per cent of each hour out of the nest running in an activity wheel (per cent Hr. R). Arrows denote sunrise and sunset. The bold lines along the horizontal axis indicate night.

an average of 30 days was used in this study. Lactating mice and their young in spring $(9,102.6$ gm-days/ha) thereby expend 5,479.8 kcal per hectare for maintenance, or 34 per cent of the population's total energy flow in spring.

Crude density in summer was 39.8 mice per hectare (Fig. 1) and the biomass-days were $53,080.8 \mathrm{gm}$ per hectare (Table 2). The average $D E B$ of nonlactating mice in summer $\left(0.307 \mathrm{kcal} / \mathrm{gm}\right.$ day $\left.=2.67 \mathrm{cc} \mathrm{O}_{2} / \mathrm{gm} \mathrm{hr}\right)$ was the least for the year (Table 1). Only in summer was the mean 
surface temperature greater than the mean temperature of the nest (Table 1). Accordingly, nonlactating animals in summer spent only 28.0 per cent of the day in the nest the remainder of the time in the activity chamber resting $(65.0 \%)$ or running $(7.0 \%$ - Table 1$)$. The oxygen consumption curve for nonlactating animals in summer again follows the typical pattern for $P$. leucopus with the greatest rate of consumption at night and a small peak about midday (Fig. 3). Energy flow for the freeliving population during summer was estimated to be $18,472.5$ kcal per hectare with 4.97 per cent of this value $(918.9 \mathrm{kcal} / \mathrm{ha})$ channeled into secondary production (Table 2). In summer lactating mice and their

Table 2

Estimated energy flow $\left(E_{f}\right)$ through a free-living population of $P$. leucopus. $E_{m}=$ energy of maintenance and $E_{q}=$ energy of growth for the population. $N-L$, represents the nonlactating portion of the population and $L+Y$ the lactating females with their young.

\begin{tabular}{|c|c|c|c|c|c|c|c|c|c|}
\hline Season & $\begin{array}{c}D E B \\
\text { (kcal/g day) }\end{array}$ & & $\begin{array}{r}\text { Biomas } \\
\text {-Days } \\
\text { (g-days } / \mathrm{h}\end{array}$ & $=$ & $\begin{array}{c}E_{m} \\
\text { (kcal/ha) }\end{array}$ & $\begin{array}{r}E_{a} \\
+(\mathrm{kcal} / \mathrm{h}\end{array}$ & $=$ & $\begin{array}{c}E_{f} \\
(\mathrm{kca} ! / \mathrm{ha})\end{array}$ & $\begin{array}{l}\% E_{f} \\
\text { in } E_{q}\end{array}$ \\
\hline Winter & 0.602 & $x$ & $48,990.5$ & $=$ & $29,492.3$ & $+\quad 71.4$ & $=2$ & $29,563.7$ & 0.24 \\
\hline \multirow{2}{*}{$\begin{array}{r}\text { Spring } \\
\mathrm{L}+\mathrm{Y}\end{array}$} & 0.485 & $x$ & $21,031.0$ & $=$ & $10,200.0$ & \multirow{2}{*}{+440.5} & \multirow{2}{*}{$=$} & \multirow{2}{*}{$16,120.3$} & \multirow{2}{*}{2.73} \\
\hline & 0.602 & $x$ & $9,102.6$ & $=$ & $5,479.8$ & & & & \\
\hline \multirow{2}{*}{$\underset{\mathrm{L}+\mathrm{Y}}{\mathrm{N}-\mathrm{L}}$} & 0.307 & $x$ & $36,746.1$ & $=$ & $11,281.1$ & \multirow{2}{*}{+918.9} & \multirow{2}{*}{$=$} & \multirow{2}{*}{$18,472.5$} & \multirow{2}{*}{4.97} \\
\hline & 0.384 & $x$ & $16,334.7$ & $=$ & $6,272.5$ & & & & \\
\hline \multirow{2}{*}{$\underset{\mathrm{L}+\mathrm{Y}}{\mathrm{N}-\mathrm{L}}$} & 0.528 & $x$ & $52,515.4$ & $=$ & $27,728.1$ & \multirow{2}{*}{+512.9} & \multirow{2}{*}{$=$} & \multirow{2}{*}{$36,575.4$} & \multirow{2}{*}{1.40} \\
\hline & 0.660 & $x$ & $12,627.9$ & $=$ & $8,331.4$ & & & & \\
\hline
\end{tabular}

young $(16,334.7$ gm-days/ha) also expended 34 per cent $(6,272.5 \mathrm{kcal} / \mathrm{ha})$ of the total energy flow for maintenance and lactation (Table 2).

Six lactating animals and their litters were studied in the laboratory during summer. The mean daily energy budget (Table 1) of these animals and their young $\left(0.384 \mathrm{kcal} / \mathrm{gm}\right.$ day $\left.=3.33 \mathrm{cc} \mathrm{O}_{2} / \mathrm{gm} \mathrm{hr}\right)$ was 24.8 per cent greater than that of nonlactating animals during the same season, but was not significantly different. Even though temperatures in the nest and activity chamber were similar to those for other animals from this season, the activity patterns were quite different. Lactating animals spent 67.3 per cent of the day in the nest, 27.7 per cent outside the nest not running on the activity wheel, and 6.9 per cent running on the activity wheel (Table 1). The 24-hour pattern of activity of the lactating animals exhibited three nearly equally spaced peaks in activity out of the 
nest (Fig. 3). The oxygen consumption curve was similar to this cycle. Energy flow for this group of animals was not distinguished separately as in the other groups, but instead was incorporated into the total energy flow for the summer season as given above.

During autumn the crude density (39.76 animals/ha, see Fig. 1) and biomass-days $(65,143.0 \mathrm{gm}$-days/ha) were the greatest of any season studied (Table 2). The average $D E B$ for nonlactating animals in autumn $\left(0.528 \mathrm{kcal} / \mathrm{gm}\right.$ day $\left.=4.59 \mathrm{cc} \mathrm{O}_{2} / \mathrm{gm} \mathrm{hr}\right)$ was greater than in summer but still less than the yearly high in winter (Table 1). In autumn, as in all seasons except summer, the mean temperature of the external environment was less than the temperature of the nest (Table 1). The amount of time spend in the nest $(63.9 \%)$ was greater than that spent outside the nest (Table 1). The 24-hour activity pattern and oxygen consumption curve (Fig. 2) is similar to those for other seasons. Energy flow during autumn was the greatest for the year $(36,575.4 \mathrm{kcal} / \mathrm{ha})$ but energy channeled into secondary production $(1.40 \%$ of total energy flow) was less than in spring and summer (Table 2). The energy expended by lactating females and their young $(8,334.4 \mathrm{kcal} / \mathrm{ha})$ was 23.0 per cent of the total energy flow, less than that $(34 \%)$ used for reproduction in spring and summer.

Different intensities of moonlight were not found to have a significant effect upon daily energy budgets or activity patterns either within a season or throughout the year. The average $D E B$ (all seasons combined) other moon phases (one-half moon, $0.355 \mathrm{kcal} / \mathrm{gm}$ day; three-quarter moon ( $0.525 \mathrm{kcal} / \mathrm{gm}$ day) were higher than the $D E B \mathrm{~s}$ of days with other moon phases (one-half moon, $0.355 \mathrm{kcal} / \mathrm{gm}$ day; three-quarter moon, $0.408 \mathrm{kcal} / \mathrm{gm}$ day; full moon, $0.374 \mathrm{kcal} / \mathrm{gm}$ day) but not significantly so.

\section{DISCUSSION}

The purpose of several recent studies in small mammal bioenergetics has been to determine a daily energy budget for the population. The daily energy budget, as defined by the Polish researchers (e.g. Groàzinski \& Górecki, 1967), is the amount of energy expended by the animal while carrying on maintenance life processes and includes such functions as thermoregulation (both inside and outside the nest), normal daily activity, and the cost of reproduction. The average daily metabolic rate $(A D M R)$ is used as the basis for computing $D E B \mathrm{~S}$ in many studies (e.g. Gę b czyński, 1966; Grodziński \& Gór e cki, 1967; Górecki, 1968). The $A D M R$ is an average of measurements of metabolism made during a 24 -hour period at a temperature similar to that of the animal's natural habitat and takes into account energy 
experditure for specific dynamic action $(S D A)$, thermoregulation, and volurtary activity (Grodziński \& Górecki, 1967). However, due to the design of the respirometers used in most investigations (e. g. G órecki, 1968; Gębczynska, 1970) activity outside is at the same temperature as in the nest and, thus, the cost of thermoregulation while active (which in the field is usvally at a temperature different than that in the nest) is not measured directly. Therefore, to construct a $D E B$ the energy used for thermoregulation outside the nest must be calculated, usually from a thermoregulatory curve constructed on the basis of the resting metabolic rate at different temperatures, and added to the $A D M R$.

Chew \& Chew (1970) described the energy of maintenance as »... the energy dissipated by a resting animal... plus the additional energy expended in activity...." This definition takes into consideration thermoregulatory expenses in and out of the nest as well as the cost of activity.

To determine the energy of maintenance Chew \& Chew (1970) constructed a formula indicating the time and energy expended by an animal resting in the nest, resting outside the nest and active outside the nest. Their formula is equivalent to:

$$
E_{m}=D \times G\left[\left(H_{n} \times E_{r n}\right)+\left(H_{o} \times E_{r a}\right)+\left(H_{o} \times I\right)\right]
$$

where $E_{m}=$ energy expended in the maintenance of body functions,

$D=$ duration of period in days,

$G=$ biomass per unit of area,

$H_{n}=$ hours per day resting in the nest,

$E_{r n}=$ rate of metabolism while resting at nest temperature,

$H_{o}=$ hours per day outside the nest,

$E_{r a}=$ rate of metabolism while resting at the temperature of the air outside the nest, and

$I$ = intensity of activity outside the nest.

This formula for the energy of maintenance would describe the $D E B$ of an animal if allowances were made for the energy expended by a female during pregnancy and lactation.

It is apparent that the energy expended for maintenance, and therefore the $D E B$, is influenced by any factor or factors affecting one or more components of the model of the $D E B$ given in this paper, which is based on the above formula of $\mathrm{Ch}$ ew \& $\mathrm{Ch}$ ew (1970). Among such factors are those which influence the activity patterns of small mammals. Two of the most important of these are the interrelated factors of temperature (F a lls, 1953; H a r t, 1953; Orr, 1959) and light (B ehney, 1936; B la ir, 1951; F a lls, 1953; O r r, 1959; K a van a u, 1962, 1967; K ing, 1968). The ambient temperature to which an endotherm is exposed greatly affects the animal's metabolism as any temperature above or below the individual's thermoneutral zone requires the expenditure of energy, to maintain a constant body temperature ( $\mathrm{M} \mathrm{c} \mathrm{N} \mathrm{a} \mathrm{b,} \mathrm{1963).} \mathrm{Light,}$ 
to the extent that it influences the daily activity pattern of the animal, is important indirectly in determining the temperature the animal will experience.

The $D E B$ and time spent in the nest by Peromyscus leucopus are inversely related to the temperature outside the nest. The white-footed mouse spends the greatest amount of the time in the nest during winter when the temperature outside the nest is least. During this season the nest temperature more nearly approximates their thermopreferendum than the outside temperature. As the outside temperature increased in spring and summer, both time spend in the nest and DEB decreased. As the cost of thermoregulation outside the nest decreases with the rise in temperature of the external environment the animals are willing to spend a greater amount of time outside the nest (in both activity and rest). In spring the temperatures inside and outside the nest were similar and the animals spent nearly equal amounts of time in each area. During summer, the warmest season, the animals spend more of their time out of the nest than in the nest. This is the only season where the temperature outside the nest is greater than that inside the nest, and it appears that temperature has a very strong influence on the animals' activity pattern. As the temperature begins to decline during autumn, the time spent in the nest and the $D E B$ increase. In all seasons the basic strategy of the species appears to be to spend the greater amount of time at temperatures closest to their thermoneutral zone and thereby minimize the cost of thermoregulation and allow more energy to be channeled into other areas (e. g. reproduction and growth in the summer), or to simply reduce the cost of existing. It may be that in late winter, when the cost of thermoregulation is highest and food supplies are lowest, all of the available energy must be used for maintenance just to survive, thereby excluding reproduction in this season.

There was no appreciable difference in the activity patterns and the metabolic rates of $P$. leucopus during different phases of the moon. The failure of moonlight to either stimulate or retard activity of the whitefooted mouse may be due to the habitat in which they live. On the central Great Plains, P. leucopus occurs primarily in wooded riparian habitats (Choate \& F leharty, 1975) which usually have sufficiently clense cover to exclude aerial predators and abundant brush and fallen trees to provide hiding places from terrestrial predators. In this type of habitat bright moonlight probably would not make the white-footed mouse more susceptible to predators and therefore influence its activity.

That bright light does not completely retard activity of the whitefooted mouse outside the nest is also shown by the increase in meta- 
bolic rate and activity at about midday during all seasons. This daylight behavior recorded in the laboratory is confirmed by our observations of $P$. leucopus in the field during the day. Other authors (B e hn e y, 1936; Orr, 1959) have also commented on the diurnal activity of $P$. leucopus and, at least when food is scarce, this is probably a common occurrence.

Acknowledgments: We wish to thank Mr. Rod S m r cka for the field data on population structure and secondary production. Mr. John Brethour (Fort Hays Agric. Exp. Sta.) provided invaluable help with statistical treatment of the data, and Dr. Jerry R. Choate (Fort Hays Kansas State Coll.) provided many helpful suggestions in reviewing the manuscript.

\section{REFERENCES}

1. Andrzejewski R., 1963: Processes of incoming, settlement and disappearance of individuals and variations in the numbers of small rodents. Acta theriol., 7: $169-213$

2. Andrzejewski R., 1967: Estimation of the abundance of small rodent populations for the use of biological productivity investigations. [In: „Secondary productivity of terrestrial ecosystems«. Ed. K. Petrusewicz]. Polish Sci. Publ. 1: 275-282. Warszawa-Kraków.

3. Ba a r S. L. \& Fleharty E. D., 1973: A respirometer for determination of metabolic rates and activity patterns under simulated natural conditions. Acta theriol., 18, 22: 435-441.

4. Behney W. H., 1936: Nocturnal explorations of the forest deer-mouse. J. Mammal., 17: 225-230.

5. B la ir W. F., 1951: Population structure, social behavior, and environmental relations in a natural population of the beach mouse, Peromyscus polionotus leucocephalus. Contr. Lab. Vert. Biol. Univ. Mich., 48: 1-47.

6. Chew R. M. \& Chew A. E., 1970: Energy relationships of the mammals of a desert shrub (Larrea tridentata) community. Ecol. Monographs, 40: 1-21.

7. Choate J. R. \& Fleharty E. D., 1975: The mammals of Ellis County, Kansas. Occas. Papers. The Museum, Texas Tech Univ., 37: 1-80.

8. F a 11 s B. J., 1953: Activity and local distribution of deer mice in relation to certain environmental factors. Unpublished $\mathrm{Ph}$. D. dissertation, Univ. Toronto, Canada.

9. Fleharty E. D. \& Choate J. R., 1973: Bioenergetic strategies of the cotton rat, Sigmodon hispidus. J. Mammal., 54: 680-692.

10. Fleharty E. D. \& Mares M. A., 1973: Habitat preference and spatial relations of Sigmodon hispidus on a remnant prairie in west-central Kansas. Southwestern Nat., 18: 21-29.

11. Gębczyńska Z., 1970: Bioenergetics of a root vole population. Acta theriol., 15, 3: 33-66.

12. Gębczyński M., 1966: The daily energy requirement of the yellow-necked field mouse in different seasons. Acta theriol., 11, 17: 391-398.

13. Gessaman J. A., 1973: Final comments. [In: „Ecological energetics of homeotherms". Ed. J. A. Gessaman]. Monograph series, Utah State Univ. Press, 20: 148-155, Logan, Utah.

14. Golley F. B., 1960: Energy dynamics of a food chain of an old-field community. Ecol. Monographs, 30: 187-206. 
15. Górecki A., 1968: Metabolic rate and energy budget in the bank vole. Acta theriol., 13, 20: 341-365.

16. Grodziński W. \& Górecki A., 1967: Daily energy budgets of small rodents. [In: "Secondary productivity of terrestrial ecosystems«. Ed. K. Petrusewicz]. Polish Sci. Publ. 1: 295-314. Warszawa-Kraków.

17. Hall E. R. \& Kelson K. R., 1959: The mammals of North America. Ronald Press, 2: viii $+547-1083+79$, New York.

18. Hansen C. \& Fleharty E. D., 1974: Structural ecological parameters of a population of Peromyscus maniculatus in west-central Kansas. Southwestern Nat., 19: 293-303.

19. Hart J. S., 1953: Energy metabolism of the white-footed mouse, Peromyscus leucopus noveboracensis, after acclimation at various environmental temperatures. Can. J. Zool., 31: 99-105.

20. Kavanau J. L., 1962: Twilight transitions and biological rhythmicity. Nature, 194: 1293-1295.

21. Kavanau J. L., 1967: Behavior of captive white-footed mice. Science, 155: $1623-1639$.

22. King J. A., 1968: Psychology. [In: "Biology of Peromyscus (Rodentia)«. Ed. J. A. King]. Spec. Publ., The Amer. Soc. Mammal.: 496-542.

23. L a y n e J. N., 1954: The biology of the red squirrel, Tamiasciurus hudsonias loquax (Bangs), in central New York. Ecol. Monographs, 24: 227-267.

24. Layne J. N., 1968: Ontogeny. [In: »Biology of Peromyscus (Rodentia)«. Ed. J. A. King]. Spec. Publ., The Amer. Soc. Mammal.: 148-253.

25. $\mathrm{M} \mathrm{c} \mathrm{N} \mathrm{a} \mathrm{b} \mathrm{B.} \mathrm{K.,} \mathrm{1963:} \mathrm{A} \mathrm{model} \mathrm{of} \mathrm{the} \mathrm{energy} \mathrm{budget} \mathrm{of} \mathrm{a} \mathrm{wild} \mathrm{mouse.} \mathrm{Ecology,}$ 44: $521-532$.

26. Odum E. P., 1971: Fundamentals of Ecology. W. B. Saunders Co.: xiv + +574. Philadephia.

27. Or r H. D., 1959: Activity of white-footed mice in relation to environment. J. Mammal., 40: 213-221.

28. Ryszkowski L. \& Petrusewicz K., 1967: Estimation of energy flow through small rodent populations. [In: "Secondary productivity of terrestrial ecosystems«. Ed. K. Petrusewicz]. Polish Sci. Publ. 1: 125-146. WarszawaKraków.

29. Smrcka R. L., 1974: Population parameters of a population of Peromyscus leucopus in west-central Kansas. Unpublished M. S. Thesis, Fort Hays Kansas State College, ii $+27 \mathrm{pp}$.

Accepted, December 3, 1975.

Stephen L. BAAR i Eugene D. FLEHARTY

\section{DOBOWY BUDŻET ENERGETYCZNY I PRZEPEYW ENERGII} PRZEZ POPULACJE PEROMYSCUS LEUCOPUS

\section{Streszczenie}

Zbadano dobowy budżet energetyczny, wzorzec aktywności i przepływ energii przez populację gryzoni Peromyscus leucopus ( $\mathrm{R}$ a finesque, 1818). Dobowy budżet energetyczny jest, u osobników niekarmiących, najwyższy w zimie i wynı- 
si $0.602 \mathrm{kcal} / \mathrm{g}$ dobę a najniższy latem $-0.307 \mathrm{kcal} / \mathrm{g}$ dobę (Tabela 1). Latem budżet ten jest dla karmiących samic o $24,8 \%$ wyższy w porównaniu do samic niekarmiących i samców (Ryc. 3). Zimą gryzonie spędzają $72 \%$ czasu doby w gnieździe, podczas gdy latem czas ten dla samców i niekarmiących samic wynosi zaledwie $28 \%$ (Ryc. 2).

Przepływ energi przez populację jest najwyższy w jesieni i wynosi $396,3 \mathrm{kcal} / \mathrm{ha}$ dobę, kiedy to stan biomasy był najwyższy (715,86 g/ha dobę - Ryc. 1). Wartość ta najniższa była wiosną (170,4 kcal/ha dobę), gdyż i stan biomasy był wtedy niski - zaledwie $327,54 \mathrm{~g} / \mathrm{ha}$ dobę (Tabela 2 ). 